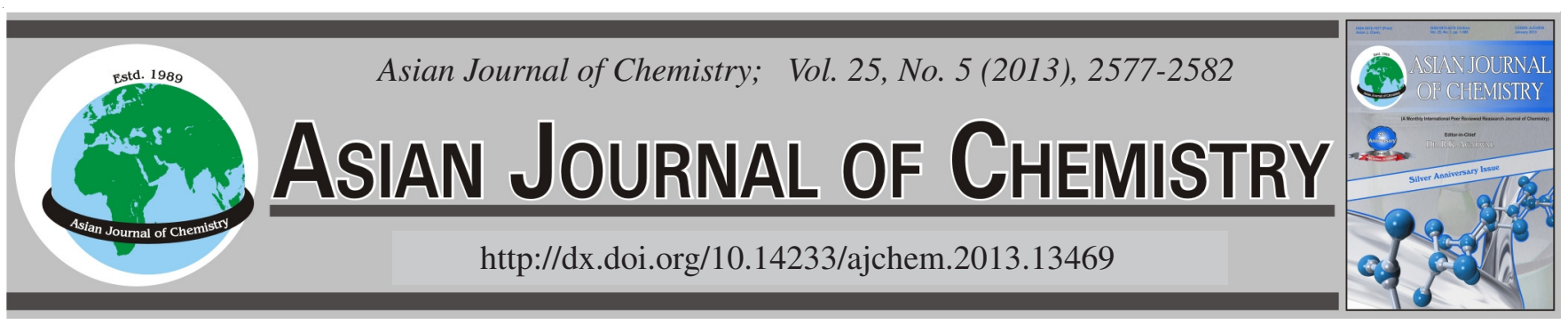

\title{
Optimization of Biodiesel Production from Siberian Apricot (Prunus sibirica L.) Oil Using Response Surface Methodology
}

\author{
L. WANG and J. CHU ${ }^{*}$
}

Key Laboratory of Tree Breeding and Cultivation, State Forestry Administration, Research Institute of Forestry, Chinese Academy Forestry, Beijing, P.R. China

*Corresponding author: Fax: +86 10 62888313; Tel: +86 10 62889649; E-mail: cjmcaf@163.com, wlibing@163.com

(Received: 18 January 2012;

Accepted: 12 November 2012)

AJC-12405

\begin{abstract}
Response surface methodology, with central composite rotatable design, was used to explore optimum conditions for the transesterification of Siberian apricot oil. The effect of five-level four factors and their reciprocal interactions were studied. A total of 30 experiments was conducted and designed to study the effect of catalyst concentration, methanol/oil molar ratio, reaction temperature and reaction time on the biodiesel yield. A second-order polynomial regression model was fitted and found adequate with $\mathrm{R}^{2}$ of 0.9942 . When the transesterification was carried out at $67^{\circ} \mathrm{C}$, with a 7.3:1 methanol/oil molar ratio to Siberian apricot oil, a reaction time of 60 min and a catalyst amount of $1.18 \%$ wt, the conversion of Siberian apricot oil was $92.9 \%$. The most fuel properties of Siberian apricot methyl esters were found to be within the EN 14214-2005 and ASTM D6751-2003 biodiesel standards.
\end{abstract}

Key Words: Siberian apricot, Biodiesel, Optimization, Response surface methodology, Fuel properties.

\section{INTRODUCTION}

With the increasing energy demand and pollution problems caused by the fossil fuels, it is time to develop alternative fuels and the renewable sources of energy. Biodiesel, which consists of mono alkyl esters of long chain fatty acids, has become a popular and environment-friendly fuel in terms of renewability, emissions, security and biodegradability ${ }^{1}$. Biodiesel is produced through a chemical process called transesterification in which triglycerides are allowed to react with an alcohol under acidic or basic catalytic conditions producing free glycerol and the fatty acid esters of the respective alcohol ${ }^{2}$. The biodiesel production yield of the reaction mainly depends upon nature of the raw oil, methanol/oil molar ratio, catalyst concentration, temperature and reaction time.

The use of low cost feedstocks such as waste cooking oils and non-conventional seed oils can reduce biodiesel production costs and increase supply while avoiding the food versus fuel problem ${ }^{3}$. Therefore, it is necessary to search for non-conventional feedstocks for biodiesel production. Though there are studies about use of non-conventional oils in biodiesel production, there exists no thorough and systematic study about potential of Siberian apricot oil in production of biodiesel fuel. Siberian apricot is widely distributed in the northern and northeastern regions in China with a total area of about 1700,000 $\mathrm{ha}^{4,5}$ and the yield of the seed kernel oil is about $50 \%$. In addition, Siberian apricot is gaining importance due to the fewer crop husbandry management practices required. For those reasons, Siberian apricot as a non-conventional species for biodiesel production, its seed kernel is an appreciable source of oil ${ }^{6}$.

Siberian apricot (Prunus sibirica L.), a member of the family Rosaceae and the genus Prunus, is one of the flowering plants. It is a deciduous shrub native to the temperate, continental, mountainous region, which includes eastern Siberia regions (Southern Trans-Baikal), Maritime territory (Southern Ussuri region) of Russia, eastern and southeastern regions of Mongolia, northern and north-eastern regions of China ${ }^{4,5}$. It grows in temperate climates and thrives with abundant solar radiation, low temperature, strong wind, low rainfall and poor soil, often growing with oak and Manchurian apricot [Prunus mandshurica (Maxim.) Skv. $]^{5,7}$. The habitual use of Siberian apricot focuses on its ecological benefits, such as water and soil conservation, windbreak, sand fixation, environment protection and greening ${ }^{8}$. The seed kernel oil of the Siberian apricot can be used for edible oils, lubricants, cosmetics, surfactants and in the prevention of cardiovascular diseases and lowering of plasma cholesterol levels ${ }^{9}$. However, the seed kernel of Siberian apricot contains amygdalin that can decompose into glucose, benzaldehyde and hydrocyanic acid by the enzyme. In small quantities, hydrogen cyanide has shown the effects to stimulate respiration and improve digestion as well 
as be good for the treatment of cancer ${ }^{10}$. In excess quantity, conversely, it can cause respiratory failure and even death ${ }^{11}$. Siberian apricot seed kernel oil thus cannot be massively used for food or medicinal production. Therefore, Siberian apricot as a non-conventional species for biodiesel production, its seed kernel is an appreciable source of oil.

The experiment model of biodiesel synthesis is developed using response surface methodology can simulate the reaction under various transesterification conditions with satisfactory estimations of errors ${ }^{12}$. This is helpful when mass production of the biodiesel is needed. In this study, the main focus is given to optimize the operating conditions for the enhancement of Siberian apricot oil-based biodiesel production. Central composite rotatable design (CCRD) was used to design the experiments and response surface methodology (RSM) was carried out for process optimization. The prediction of the optimum operating conditions to obtain the higher yield of desired product was studied using suitable modeling techniques from response surface methodology and design of experiments.

\section{EXPERIMENTAL}

The seeds of fully matured Siberian apricot ( $P$. sibirica L.) fruits were collected in July 2010 in the Balinyou National Tractor Ploughing Forest Farm, Chifeng City, Inner Mongolia Autonomous Region, China (geographical coordinates approximately $43^{\circ} 44^{\prime} \mathrm{N}, 118^{\circ} 44^{\prime} \mathrm{E}$ ). The fresh seeds were stored at room temperature for one week to dry before they were transferred to the laboratory in polypropylene bags under cool conditions. Kernels were obtained from hulls and stored.

Pure fatty acid methyl esters were purchased from Sigma Chemical Co. (USA). Methanol, potassium hydroxide and all other regents (AR) were from Sinopharm Chemical Reagent Co. Ltd., Beijing.

Extraction of seed kernel oil: The kernels of Siberian apricot seeds were crushed using a domestic grinder giving a mean particle size of the milled kernels of $0.8 \mathrm{~mm}$. Fat components were extracted with petroleum ether using a Soxhlet apparatus at $45-50{ }^{\circ} \mathrm{C}$. The oil content was determined as the difference in weight of the dried kernel sample before and after the extraction.

Experimental design: The Siberian apricot biodiesel synthesis was developed and optimized using response surface methodology provided by design-expert software 8.0.6. A five-level-four-factor central composite rotatable design was employed in this study, requiring 30 experiments $\left(=2^{4}+2 \times 4\right.$ $+6)$. Four identified independent variables are A: catalyst loading (0.6-1.2wt. \%), B: methanol to oil molar ratio (4:1$8: 1)$, C: reaction temperature $\left(50-70{ }^{\circ} \mathrm{C}\right)$ and $\mathrm{D}$ : reaction time (30-60 min). Coded and uncoded levels of the independent variables are given in Table-1. Three replications were carried out for all design points and the experiments were carried out in randomized order.

Transesterification experiments: Table- 3 shows the design matrix of the experiments and their corresponding results. The very low acid value of the Siberian apricot oil enabled direct base-catalyzed transesterification for biodiesel production without acid pretreatment ${ }^{5}$. A $500 \mathrm{~mL}$ three-necked round-bottomed reactor, equipped with thermostat, sampling

\begin{tabular}{|c|c|c|c|c|c|c|c|}
\hline \multirow{3}{*}{ Factors } & \multicolumn{5}{|c|}{$\begin{array}{c}\text { TABLE-1 } \\
\text { FACTORS AND THEIR LEVELS FOR } \\
\text { CENTRAL COMPOSITE DESIGN }\end{array}$} & & \\
\hline & \multirow{2}{*}{ Coding } & \multirow{2}{*}{ Units } & \multicolumn{5}{|c|}{ Levels } \\
\hline & & & -2 & -1 & 0 & 1 & 2 \\
\hline $\begin{array}{l}\text { Catalyst } \\
\text { loading }\end{array}$ & $\mathrm{X}_{1}$ & wt. \% & 0.6 & 0.8 & 1.0 & 1.2 & 1.4 \\
\hline $\begin{array}{l}\text { Methanol/oil } \\
\text { molar ratio }\end{array}$ & $\mathrm{X}_{2}$ & $\mathrm{~mol} / \mathrm{mol}$ & $4: 1$ & $5: 1$ & $6: 1$ & $7: 1$ & $8: 1$ \\
\hline $\begin{array}{l}\text { Reaction } \\
\text { temperature }\end{array}$ & $X_{3}$ & ${ }^{\circ} \mathrm{C}$ & 50 & 55 & 60 & 65 & 70 \\
\hline $\begin{array}{l}\text { Reaction } \\
\text { time }\end{array}$ & $\mathrm{X}_{4}$ & $\min$ & 40 & 50 & 60 & 70 & 80 \\
\hline
\end{tabular}

outlet, a reflux condenser and a mechanical stirrer (set at 600 rpm stirring rate) was used for transesterification of Siberian apricot oil ${ }^{2} .100 \mathrm{~g}$ of Siberian apricot kernel oil was transferred to the flask, which was pre-heated to desired temperatures on a heating plate before starting the reaction. A specified amount of alcoholic $\mathrm{KOH}$ was added to a predetermined amount of anhydrous methanol and the mixture was stirred until $\mathrm{KOH}$ dissolved completely. The methanol-KOH solution was added to the pre-heated Siberian apricot oil and stirred for required reaction time. After the transesterification reaction, the mixture was allowed to cool down and equilibrate for overnight. The reaction product will be separated to two layers with the upper layer being biodiesel and the lower layer being glycerol ${ }^{13}$. This was followed by conventional work-up consisting of separation of phases, washing the resulting methyl esters with water until the water was neutral and drying with magnesium sulfate. The upper layer will be further analyzed by gas chromatography to determine the biodiesel yield.

Biodiesel yield: The fatty acid methyl ester composition of the purified Siberian apricot biodiesel samples was determined by gas chromatography-mass spectrometry (GC-MS). The hexane $(1 \mu \mathrm{L})$ extract was injected into a highly polar HP Innowax capillary column of $30 \mathrm{~m}$ length (inner diameter $0.32 \mathrm{~m}$, filmthickness $0.5 \mathrm{~mm}$, split 1:20). An Agilent 6890 (California, USA) equipped with flame ionization detector (FID) was used. The injector and detector temperatures were $250{ }^{\circ} \mathrm{C}$ and $280^{\circ} \mathrm{C}$, respectively. Oven temperature was programmed from $190{ }^{\circ} \mathrm{C}$ holding at $3 \mathrm{~min}$ to $240^{\circ} \mathrm{C}$ at the rate of $15^{\circ} \mathrm{C} / \mathrm{min}$ for $17 \mathrm{~min}$. The carrier gas was high-purity hydrogen. Peaks of fatty acid methyl esters were identified by comparing their retention time with that of the known standards, run under similar separation conditions. Peak integration was performed by applying HP3398A software. The yield of biodiesel can be calculated using the following equation:

Biodiesel yield (wt. \%) $=\frac{\text { Amount of FAME }(\mathrm{g})}{\text { Amount of oil used }(\mathrm{g})} \times 100 \%$

Statistical analysis: Data obtained from central composite rotatable design for optimization of reaction conditions was used for determining the regression coefficients of the secondorder multiple regression model.

$$
\mathrm{Y}_{\text {yield }}=\mathrm{b}_{0}+\sum_{\mathrm{i}=1}^{4} \mathrm{~b}_{\mathrm{i}} \mathrm{x}_{\mathrm{i}}+\sum_{\mathrm{i}=1}^{4} \mathrm{~b}_{\mathrm{ij}} \mathrm{x}_{\mathrm{i}}^{2}+\sum_{\mathrm{i}_{\mathrm{i}>\mathrm{j}}}^{4} \sum_{\mathrm{j}}^{4} \mathrm{~b}_{\mathrm{ij}} \mathrm{x}_{\mathrm{i}} \mathrm{x}_{\mathrm{j}}+\mathrm{e}
$$

where, $Y_{\text {yield }}$ is the predicted biodiesel yield variable; $i$ and $j$ are the linear and quadratic coefficients, respectively; $b_{0}$ is the 


\begin{tabular}{|c|c|c|c|c|c|c|c|}
\hline \multirow{3}{*}{ Std } & \multicolumn{6}{|c|}{$\begin{array}{l}\text { TABLE-2 } \\
\text { CENTRAL COMPOSITE ROTATABLE SECOND-ORDER DESIGN, EXPERIMENTAL AND } \\
\text { ESTIMATED DATE FOR FIVE-LEVEL, FOUR-FACTOR RESPONSE ANALYSIS }\end{array}$} & \\
\hline & \multirow{2}{*}{$\begin{array}{c}\text { Catalyst } \\
\text { loading }(\%)\end{array}$} & \multirow{2}{*}{$\begin{array}{l}\text { Methanol/oil molar } \\
\text { ratio }(\mathrm{mol} / \mathrm{mol})\end{array}$} & \multirow{2}{*}{$\begin{array}{l}\text { Reaction temp. } \\
\left({ }^{\circ} \mathrm{C}\right)\end{array}$} & \multirow{2}{*}{$\begin{array}{c}\text { Reaction } \\
\text { time (min) }\end{array}$} & \multicolumn{3}{|c|}{ Yield (\%) } \\
\hline & & & & & Exp. & Estimated & Residual values \\
\hline 1 & 1.0 & $6: 1$ & 60 & 80 & 88.2 & 88.4 & -0.2 \\
\hline 2 & 0.8 & $5: 1$ & 65 & 70 & 84.6 & 84.8 & -0.2 \\
\hline 3 & 0.8 & $5: 1$ & 65 & 50 & 83.6 & 83.3 & 0.3 \\
\hline 4 & 1.2 & $5: 1$ & 65 & 50 & 86.6 & 86.4 & 0.2 \\
\hline 5 & 1.2 & $5: 1$ & 55 & 50 & 83.4 & 83.2 & 0.2 \\
\hline 6 & 1.2 & $5: 1$ & 55 & 70 & 84.4 & 84.7 & -0.3 \\
\hline 7 & 0.8 & $7: 1$ & 65 & 50 & 87.5 & 87.1 & 0.4 \\
\hline 8 & 1.0 & $6: 1$ & 60 & 60 & 88.4 & 88.4 & 0 \\
\hline 9 & 0.8 & $5: 1$ & 55 & 70 & 81.7 & 81.8 & -0.1 \\
\hline 10 & 1.0 & $8: 1$ & 60 & 60 & 89.3 & 89.8 & -0.5 \\
\hline 11 & 1.0 & $6: 1$ & 60 & 60 & 88.2 & 88.4 & -0.2 \\
\hline 12 & 1.4 & $6: 1$ & 60 & 60 & 88.8 & 89.2 & -0.4 \\
\hline 13 & 1.0 & $6: 1$ & 50 & 60 & 79.9 & 80.5 & -0.6 \\
\hline 14 & 1.0 & $4: 1$ & 60 & 60 & 82.5 & 82.7 & -0.2 \\
\hline 15 & 1.2 & $7: 1$ & 65 & 50 & 90.8 & 90.4 & 0.4 \\
\hline 16 & 0.8 & $7: 1$ & 65 & 70 & 89.4 & 89.5 & -0.1 \\
\hline 17 & 1.2 & $7: 1$ & 55 & 70 & 87.6 & 87.8 & -0.2 \\
\hline 18 & 1.2 & $5: 1$ & 65 & 70 & 87.7 & 88.0 & -0.3 \\
\hline 19 & 0.8 & $5: 1$ & 55 & 50 & 80.5 & 80.4 & 0.1 \\
\hline 20 & 0.8 & $7: 1$ & 55 & 70 & 84.7 & 84.9 & -0.2 \\
\hline 21 & 1.0 & $6: 1$ & 60 & 60 & 88.6 & 88.4 & 0.2 \\
\hline 22 & 1.2 & $7: 1$ & 65 & 70 & 92.7 & 92.8 & -0.1 \\
\hline 23 & 1.0 & $6: 1$ & 60 & 60 & 88.2 & 88.4 & -0.2 \\
\hline 24 & 1.0 & $6: 1$ & 60 & 60 & 88.1 & 88.4 & -0.3 \\
\hline 25 & 1.0 & $6: 1$ & 60 & 60 & 88.4 & 88.4 & 0 \\
\hline 26 & 0.8 & $7: 1$ & 55 & 50 & 83.1 & 82.6 & 0.5 \\
\hline 27 & 0.6 & $6: 1$ & 60 & 60 & 82.8 & 83.1 & -0.3 \\
\hline 28 & 1.0 & $6: 1$ & 70 & 60 & 88.2 & 88.3 & -0.1 \\
\hline 29 & 1.0 & $6: 1$ & 60 & 40 & 84.2 & 84.7 & -0.5 \\
\hline 30 & 1.2 & $7: 1$ & 55 & 50 & 85.9 & 85.6 & 0.3 \\
\hline
\end{tabular}

offset term, $b_{j}$ is the linear effect, $b_{i j}$ is the first order interaction effect, $b_{\mathrm{jj}}$ is the squared effect and $e$ is the random error. Designexpert software 8.0.6 was used for regression analysis and analysis of variance (ANOVA). Response surfaces and contour plots were developed using the quadratic polynomial equation obtained from regression analysis of experimental data by keeping two of the independent variables at a constant value while changing the other two variables.

Fuel properties of the methyl ester: Fuel properties of the methyl ester were determined according to ASTM and EN standard methods: density (ASTM D5002), kinematic viscosity at $40{ }^{\circ} \mathrm{C}$ (ASTM D445), flash point (ASTM D93), cold filter plugging point (ASTM D6371), sulfur content (ASTM D4294), water content (ASTM D95), copper strip corrosion (ASTM D130), cetane number (ASTM D6890), oxidative stability (EN 14112), acid value (ASTM D664), free glycerol (ASTM D6584) and total glycerol (ASTM D6584) were determined following standard procedures as specified.

\section{RESULTS AND DISCUSSION}

Date analysis: Using response surface methodology for analysis of experimental parameters, a quadratic polynomial equation was generated to fit the experimental data. Table- 2 listed the experimental factor settings and results based on experimental design. All 30 experiments were conducted and the results were analyzed via multiple regression. To fit the empirical model to the response variable data regression analysis approach was employed. A polynomial equation [Eq.(2)], was used to correlate the four independent variables with the response acquired in Table- 2 by means of multiple regression analysis.

The experimental and estimated values of yield of biodiesel obtained at the designed points of different reaction conditions are shown in Table-2. The yield of biodiesel varied between $79.9 \%$ and $92.7 \%$. The minimum biodiesel yield was obtained at $1.0 \%$ catalyst loading, 6:1 methanol/oil molar ratio, $50{ }^{\circ} \mathrm{C}$ reaction temperature and $60 \mathrm{~min}$ reaction time, while the maximum value at $1.2 \%$ catalyst loading, 7:1 methanol/oil molar ratio, $65{ }^{\circ} \mathrm{C}$ reaction temperature and 70 min reaction time.

To access the goodness of fit, ANOVA was employed to the experimental results for fitting second-order response surface model by the least square methods. Table-3 depicted the significance of quadratic models and its corresponding model term for all responses. The significance of the model was tested at $95 \%$ confidence level, which showed F-value of the model (184.39) with very low probability value of the model indicated the high significance of the fitted model showing the reliability of the regression model for predicting the yield of biodiesel.

The $p$-value is used as a tool to check the significance of each regression coefficient, which also indicates the interaction 
effect of each cross-product. The smaller the $p$-value, the bigger the significance of the corresponding coefficient ${ }^{12}$. In case of the model terms, the $p$-values less than 0.05 indicated that the particular model terms were statistically significant. From the ANOVA results (Table-3), the main model terms suggested that variables with significant influence on yield of biodiesel response were catalyst loading $\left(\mathrm{X}_{1}\right)$, methanol/oil molar ratio $\left(\mathrm{X}_{2}\right)$, reaction temperature $\left(\mathrm{X}_{3}\right)$, reaction time $\left(\mathrm{X}_{4}\right)$ and the interaction terms were found to exist between the main factors (only $\mathrm{X}_{2} \mathrm{X}_{3}$ ), while the significant quadratic terms were catalyst loading $\left(\mathrm{X}_{1}^{2}\right)$, methanol/oil molar ratio $\left(\mathrm{X}_{2}^{2}\right)$, reaction temperature $\left(\mathrm{X}_{3}^{2}\right)$ and reaction time $\left(\mathrm{X}_{4}^{2}\right)$. A low value of coefficient of the variation $(\mathrm{CV}, 0.38 \%)$, indicated a high degree of precision and a good deal of reliabillity of the experimental values (Table-3).

\begin{tabular}{cccccc}
\multicolumn{7}{c}{ TABLE-3 } \\
\multicolumn{5}{c}{ ANALYSIS OF VARIANCE (ANOVA) FOR } \\
\hline RESPONSE SURFACE QUADRATIC MODEL \\
\hline Source & $\begin{array}{c}\text { Sum of } \\
\text { squares }\end{array}$ & $\begin{array}{c}\text { Degree of } \\
\text { freedom }\end{array}$ & $\begin{array}{c}\text { Mean } \\
\text { squares }\end{array}$ & $\begin{array}{c}F- \\
\text { value }\end{array}$ & $p$-value \\
\hline Model & 283.38 & 14 & 20.24 & 184.39 & $<0.0001$ \\
$\mathrm{X}_{1}$ & 54.00 & 1 & 54.00 & 491.90 & $<0.0001$ \\
$\mathrm{X}_{2}$ & 76.33 & 1 & 76.33 & 695.28 & $<0.0001$ \\
$\mathrm{X}_{3}$ & 96.80 & 1 & 96.80 & 881.80 & $<0.0001$ \\
$\mathrm{X}_{4}$ & 15.68 & 1 & 15.68 & 142.85 & $<0.0001$ \\
$\mathrm{X}_{1} \mathrm{X}_{2}$ & 0.02 & 1 & 0.02 & 0.20 & 0.6572 \\
$\mathrm{X}_{1} \mathrm{X}_{3}$ & 0.12 & 1 & 0.12 & 1.12 & 0.3075 \\
$\mathrm{X}_{1} \mathrm{X}_{4}$ & 0.00 & 1 & 0.00 & 0.00 & 1.0000 \\
$\mathrm{X}_{2} \mathrm{X}_{3}$ & 2.72 & 1 & 2.72 & 24.80 & 0.0002 \\
$\mathrm{X}_{2} \mathrm{X}_{4}$ & 0.49 & 1 & 0.49 & 4.46 & 0.0518 \\
$\mathrm{X}_{3} \mathrm{X}_{4}$ & 0.01 & 1 & 0.01 & 0.09 & 0.7669 \\
$\mathrm{X}_{1}{ }^{2}$ & 8.68 & 1 & 8.68 & 79.06 & $<0.0001$ \\
$\mathrm{X}_{2}{ }^{2}$ & 7.92 & 1 & 7.92 & 72.18 & $<0.0001$ \\
$\mathrm{X}_{3}{ }^{2}$ & 27.43 & 1 & 27.43 & 249.86 & $<0.0001$ \\
$\mathrm{X}_{4}{ }^{2}$ & 5.87 & 1 & 5.87 & 53.45 & $<0.0001$ \\
Residual & 1.65 & 15 & 0.11 & - & - \\
Lack of fit & 1.48 & 10 & 0.15 & 4.39 & 0.0581 \\
Pure error & 0.17 & 5 & 0.03 & - & - \\
Total & 285.03 & 29 & - & - & - \\
\hline C.V. $=0.38 \%, \mathrm{R}^{2}=0.9942, \mathrm{R}_{\text {adj }}{ }^{2}=0.9888$, Predicted $\mathrm{R}^{2}=0.9693$ \\
\end{tabular}

The $p$-value of the "lack of fit" was $0.0581(p>0.05)$, indicating that lack of fit was insignificant. The coefficient of determination $\left(\mathrm{R}^{2}\right)$ value was 0.9942 for the yield of biodiesel. The $R^{2}$ value provided a measure of how variability in the observed response values could be explained by the experimental factors and their interactions. The closer the $\mathrm{R}^{2}$ value to 1 , the stronger the model and better it predicts the response $\mathrm{e}^{14}$. The $\mathrm{R}^{2}$ value of 0.9942 implied that only 0.0059 of the total variation were not explained by the model. The response predicted from the empirical model was in agreement with the observed values in the range of the operating variables (Fig. 1). The adjusted determination coefficient value $\left(\mathrm{R}_{\mathrm{adj}}{ }^{2}\right)$ was 0.9888 , very close to the $R^{2}$ value, which corrects the $R^{2}$ values for the sample size and the number of terms in the model. These values indicated that the accuracy and general availability of the polynomial model was adequate. The second degree polynomial model for the yield of biodiesel was regressed as shown:

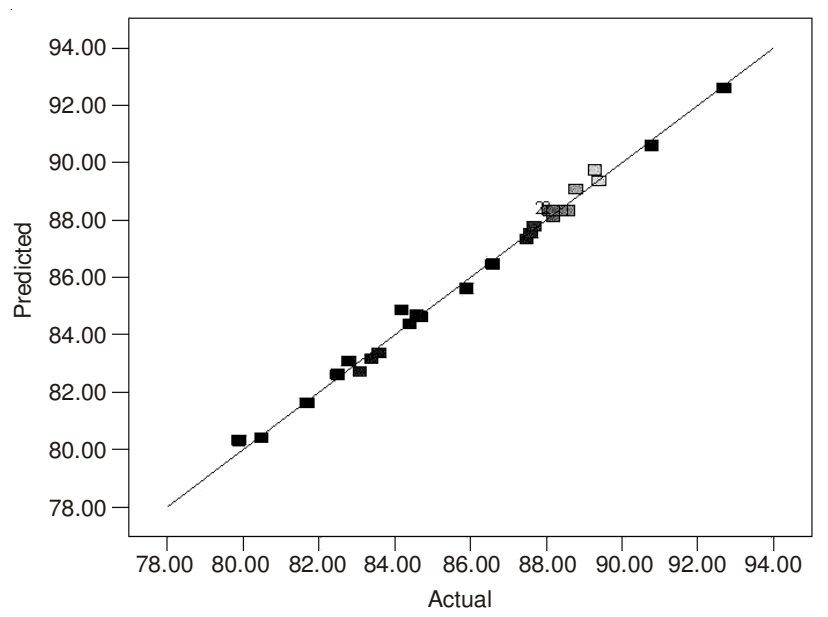

Fig. 1. Plot of actual verses predicted values

$$
\begin{gathered}
\mathrm{Y}=88.32+1.50 \mathrm{X}_{1}+1.78 \mathrm{X}_{2}+2.01 \mathrm{X}_{3}+0.81 \mathrm{X}_{4}+0.04 \\
\mathrm{X}_{1} \mathrm{X}_{2}+0.09 \mathrm{X}_{1} \mathrm{X}_{3}+0.41 \mathrm{X}_{2} \mathrm{X}_{3}+0.18 \mathrm{X}_{2} \mathrm{X}_{4}+0.02 \mathrm{X}_{3} \mathrm{X}_{4}- \\
0.56 \mathrm{X}_{1}^{2}-0.54 \mathrm{X}_{2}^{2}-1.00 \mathrm{X}_{3}^{2}-0.46 \mathrm{X}_{4}^{2}
\end{gathered}
$$

The calculated equation for the optimization of variables shows that the yield of biodiesel (Y) is a function of catalyst loading $\left(\mathrm{X}_{1}\right)$, methanol/oil molar ratio $\left(\mathrm{X}_{2}\right)$, reaction temperature $\left(X_{3}\right)$ and reaction time $\left(X_{4}\right)$. On the other hand, $X_{1} X_{2}$, $\mathrm{X}_{1} \mathrm{X}_{3}, \mathrm{X}_{2} \mathrm{X}_{3}, \mathrm{X}_{2} \mathrm{X}_{4}$ and $\mathrm{X}_{3} \mathrm{X}_{4}$ are the interactive predictors. Model coefficients and probability values (coded value) are shown in Table-4.

\begin{tabular}{ccccccc}
\multicolumn{7}{c}{ TABLE-4 } \\
\multicolumn{7}{c}{$\begin{array}{c}\text { REGRESSION COEFFICIENTS AND SIGNIFICANCE OF } \\
\text { RESPONSE QUADRATIC MODEL }\end{array}$} \\
\hline Factor & $\begin{array}{c}\text { Coefficients } \\
\text { estimate }\end{array}$ & DF & $\begin{array}{c}\text { Standard } \\
\text { error }\end{array}$ & $\begin{array}{c}95 \% \\
\text { CI low }\end{array}$ & $\begin{array}{c}95 \% \text { CI } \\
\text { high }\end{array}$ & VIF \\
\hline Intercept & 88.32 & 1 & 0.14 & 88.03 & 88.60 & \\
$\mathrm{X}_{1}$ & 1.50 & 1 & 0.07 & 1.36 & 1.64 & 1.00 \\
$\mathrm{X}_{2}$ & 1.78 & 1 & 0.07 & 1.64 & 1.93 & 1.00 \\
$\mathrm{X}_{3}$ & 2.01 & 1 & 0.07 & 1.86 & 2.15 & 1.00 \\
$\mathrm{X}_{4}$ & 0.81 & 1 & 0.07 & 0.66 & 0.95 & 1.00 \\
$\mathrm{X}_{1} \mathrm{X}_{2}$ & 0.04 & 1 & 0.08 & -0.14 & 0.21 & 1.00 \\
$\mathrm{X}_{1} \mathrm{X}_{3}$ & 0.09 & 1 & 0.08 & -0.09 & 0.26 & 1.00 \\
$\mathrm{X}_{1} \mathrm{X}_{4}$ & 0.00 & 1 & 0.08 & -0.18 & 0.18 & 1.00 \\
$\mathrm{X}_{2} \mathrm{X}_{3}$ & 0.41 & 1 & 0.08 & 0.24 & 0.59 & 1.00 \\
$\mathrm{X}_{2} \mathrm{X}_{4}$ & 0.18 & 1 & 0.08 & 0.00 & 0.35 & 1.00 \\
$\mathrm{X}_{3} \mathrm{X}_{4}$ & 0.02 & 1 & 0.08 & -0.15 & 0.20 & 1.00 \\
$\mathrm{X}_{1}{ }^{2}$ & -0.56 & 1 & 0.06 & -0.70 & -0.43 & 1.05 \\
$\mathrm{X}_{2}{ }^{2}$ & -0.54 & 1 & 0.06 & -0.67 & -0.40 & 1.05 \\
$\mathrm{X}_{3}{ }^{2}$ & -1.00 & 1 & 0.06 & -1.13 & -0.87 & 1.05 \\
$\mathrm{X}_{4}{ }^{2}$ & -0.46 & 1 & 0.06 & -0.60 & -0.33 & 1.05 \\
\hline
\end{tabular}

Effect of reaction parameters: A perturbation plot was used to compare the effect of all the parameters within a similar design space (Fig. 2). The influence of one parameter is evaluated and plotted against the yield while other parameters are kept constant. Reaction temperature (C) shows greater influence on yield of biodiesel than other parameters followed by methanol/ oil molar ratio (B), catalyst loading (A) and lastly reaction time (D). This is also reflected from the results shown in Table-3: the reaction temperature has large $F$-value (881.80) implying strongest influence on the yield followed by methanol/oil molar ratio, catalyst loading and reaction time.

Among the interaction terms that influenced the yield of biodiesel response, only the interaction effect of the methanol molar ratio $\left(\mathrm{X}_{2}\right)$ and the reaction temperature $\left(\mathrm{X}_{3}\right)$ gave the 
significant influence toward the yield of biodiesel $(p=0.0002$ $>0.05)$. The influence of interaction and response surface plots for the studied parameters are presented in Figs. 3 and 4. The interaction figures are non-parallel plots showing that there is a visible influence between one reaction parameter to another (Fig. 3). Fig. 4 showed the contour plot for the interaction effect between the methanol/oil molar ratio $\left(\mathrm{X}_{2}\right)$ and the reaction temperature $\left(\mathrm{X}_{3}\right)$ toward the yield of biodiesel. The catalyst loading $\left(\mathrm{X}_{1}\right)$ and reaction time $\left(\mathrm{X}_{4}\right)$ were fixed at $1 \mathrm{wt} \%$ and $60 \mathrm{~min}$, respectively. The contours surfaces are the graphical representation of the regression equation for the optimization of reaction conditions and the most useful approach in terms of revelation of the reaction system ${ }^{13}$. From the contour plots, it is easy and convenient to understand the interactions between two factors and also locate their optimum levels. At high level of reaction temperature, the increase of methanol/oil molar ratio greatly improves the yield of biodiesel, but it showed a little or negative effect at low level of reaction temperature and high level of methanol/oil molar ratio. In contrast, the influence of reaction temperature is not substantial at low level of methanol/oil molar ratio, but it showed linear effect when the methanol/oil molar ratio was increased (Fig. 4). This interaction effect showed positive influence on the yield of biodiesel (eqn. 3) which suggests that the interaction between methanol molar ratio and reaction temperature increased the biodiesel yield.

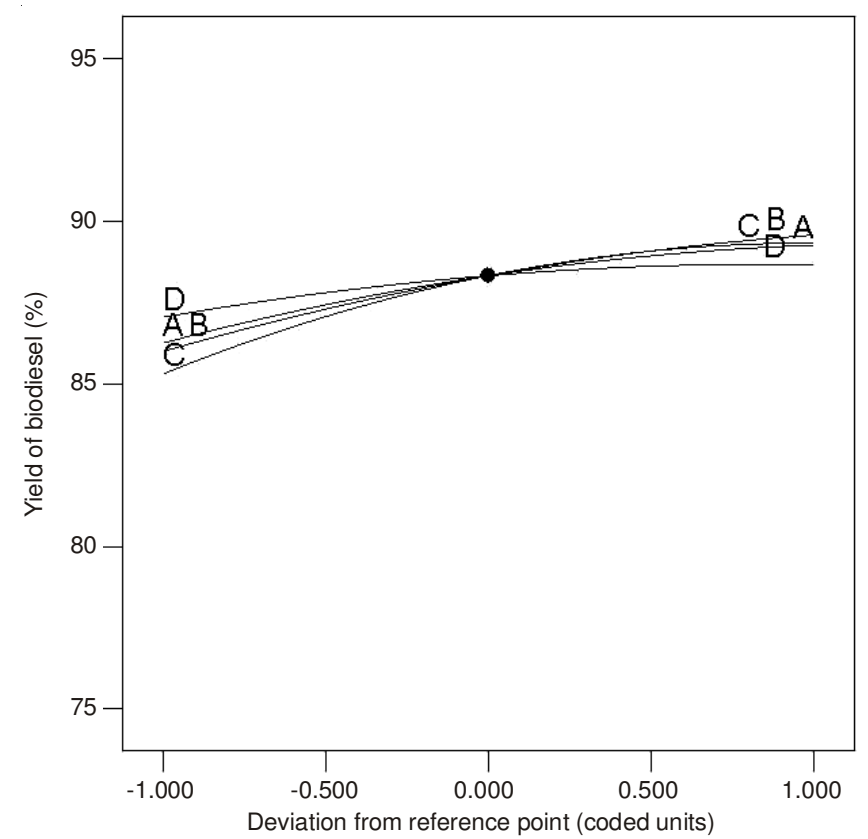

Fig. 2. Perturbation plot of the reaction parameters. (A) Catalyst loading, (B) Methanol/oil molar ratio, (C) Reaction temperature and (D) reaction time

Optimization of biodiesel yield: As the fitted model in equation (3) provides a good approximation to the experimental condition so given model was employed to find the values of the process variables for maximum yield of biodiesel phase. The optimal values of the predictors are catalyst concentration $1.18 \%$, methanol/oil molar ratio 7.3:1, reaction temperature $66{ }^{\circ} \mathrm{C}$ and reaction time $67 \mathrm{~min}$. The model predicts that the maximum yield that can be obtained under the above optimum conditions of the variables is $92.9 \%$ with standard error of prediction of 0.19 . At the optimized set of conditions, Siberian apricot biodiesel yield of $93.20 \%$ was observed.

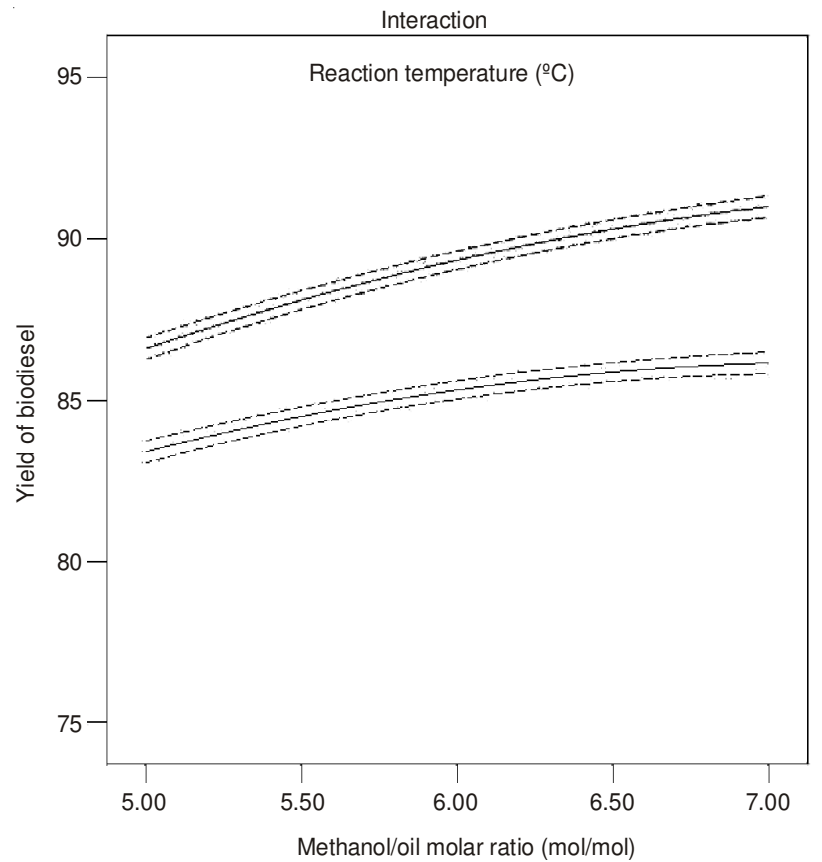

Fig. 3. Two-dimensional plot of the effect of methanol/oil molar ratio and reaction temperature on methyl esters yield

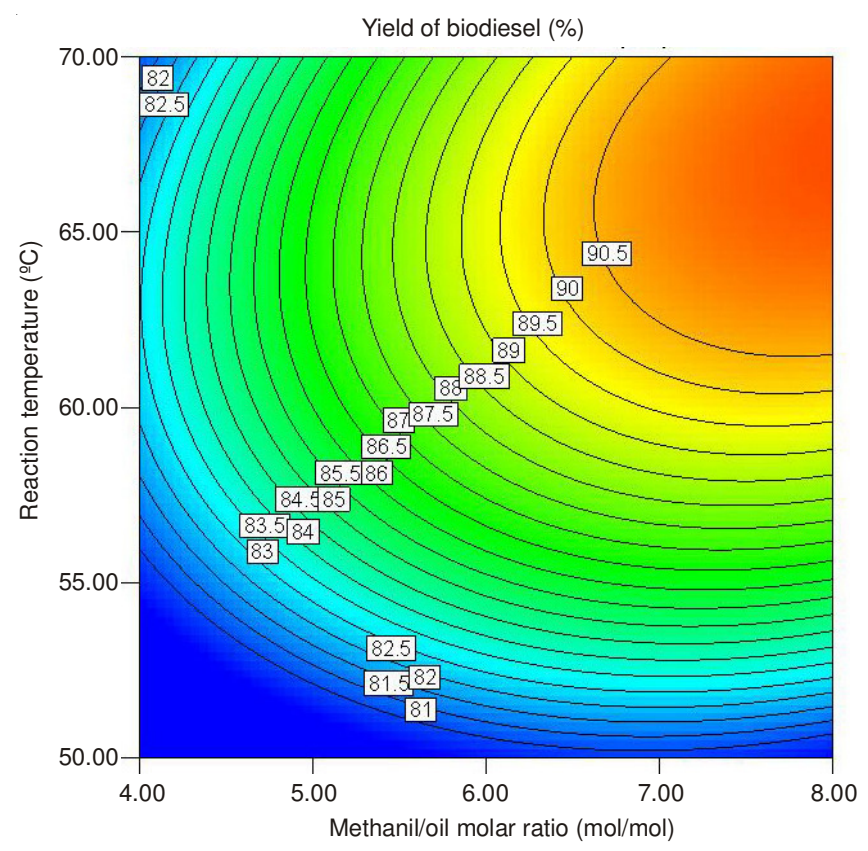

Fig. 4. Contour plot of the effect of methanol/oil molar ratio and reaction temperature on methyl esters yield

Quality of biodiesel: In order to evaluate the quality of biodiesel produced from Siberian apricot oil, the physical and chemical properties were assessed. The main fuel properties of the Siberian apricot seed kernels oil methyl esters were summarized in Table-5 together with the limits of specifications from the biodiesel American standard ASTM D6751-2003 and European standard EN 14214-2005. The most results of fuel properties compared well with EN 14214-2005 and ASTM 
D6751-2003, especially the cold flow properties were excellent $\left(\mathrm{CFPP}-14^{\circ} \mathrm{C}\right)$. The cetane number and oxidative stability would require the use of additives and antioxidants to meet specifications in biodiesel standards (Table-5).

\begin{tabular}{|c|c|c|c|}
\hline $\begin{array}{l}\text { TA } \\
\text { FUEL PROPERTIES OF SIBER } \\
\text { WITH COMPARISON T }\end{array}$ & $\begin{array}{l}\text { BLE-5 } \\
\text { IAN APRI } \\
\text { BIODIES }\end{array}$ & $\begin{array}{l}\text { COT METHY } \\
\text { EL STANDA }\end{array}$ & $\begin{array}{l}\text { L ESTERS } \\
\text { RDS }\end{array}$ \\
\hline Fuel properties & $\begin{array}{c}\text { Siberian } \\
\text { apricot }\end{array}$ & $\begin{array}{c}\text { ASTM D } \\
6751-2003\end{array}$ & $\begin{array}{l}\text { EN 14214- } \\
2005\end{array}$ \\
\hline Density $\left(\mathrm{kgm}^{-3} ; 15^{\circ} \mathrm{C}\right)$ & 878.2 & $-^{\mathrm{a}}$ & $860-900$ \\
\hline $\begin{array}{l}\text { Kinematic viscosity }\left(\mathrm{mm}^{2} \mathrm{~s}^{-1} ; 40\right. \\
\left.{ }^{\circ} \mathrm{C}\right)\end{array}$ & 4.341 & $1.9 \sim 6.0$ & $3.5-5.0$ \\
\hline Flash point $\left({ }^{\circ} \mathrm{C}\right)$ & 173 & $130 \mathrm{~min}$ & $120 \mathrm{~min}$ \\
\hline Cold filter plugging point $\left({ }^{\circ} \mathrm{C}\right)$ & -14 & $-^{\mathrm{a}}$ & $-^{\mathrm{b}}$ \\
\hline Sulfur content $\left(\mathrm{mg} \mathrm{kg}^{-1}\right)$ & 4.6 & $15 \max$ & $10 \max$ \\
\hline Water content $\left(\mathrm{mg} \mathrm{kg}^{-1}\right)$ & 400 & $500 \max$ & $500 \max$ \\
\hline $\begin{array}{l}\text { Copper strip corrosion }\left(50^{\circ} \mathrm{C} \text {; }\right. \\
3 \mathrm{~h})\end{array}$ & 1a & 3a max & 1a $\max$ \\
\hline Cetane number & 48.8 & $47 \mathrm{~min}$ & $51 \mathrm{~min}$ \\
\hline Oxidative stability $\left(\mathrm{h} ; 110^{\circ} \mathrm{C}\right)$ & 2.7 & $3.0 \mathrm{~min}$ & $6.0 \mathrm{~min}$ \\
\hline Free glycerol $\left(\mathrm{mg} \mathrm{kg}^{-1}\right)$ & 0.013 & $0.02 \max$ & $0.02 \max$ \\
\hline Total glycerol $\left(\mathrm{mg} \mathrm{kg}^{-1}\right)$ & 0.12 & $0.24 \max$ & $0.25 \max$ \\
\hline
\end{tabular}

\section{Conclusion}

The response surface methodology based on central composite rotatable design was used for the optimization transesterification of Siberian apricot oil. The biodiesel yield of Siberian apricot up to $92.9 \%$ can be achieved using the following reaction conditions: catalyst concentration $1.18 \%$, methanol/oil molar ratio $7.3: 1$, reaction temperature $66^{\circ} \mathrm{C}$ and reaction time $67 \mathrm{~min}$. Apart from that, the most properties of the biodiesel produced under optimum conditions met EN 14214-2005 and ASTM D 6751-2003 standards. The present study demonstrates the usefulness of response surface methodology for optimum conversion of Siberian apricot oil to biodiesel, which can be used as an alternative to the petrodiesel.

\section{ACKNOWLEDGEMENTS}

The author acknowledged the financial support of Special Fund for Forest Scientific Research in the Public Interest (201004001) and National Key Technology Research and Development Program of China during the 12th Five-Year Plan (2011BAD22B08) for this research.

\section{REFERENCES}

1. R. Wang, W. Zhou, M.A. Hanna, Y. Zhang, P.S. Bhadury, Y. Wang, B. Song and S. Yang, Fuel, 91, 182 (2012).

2. U. Rashid, F. Anwar, M. Ashraf, M. Saleem and S. Yusup, Energ. Conv. Manage., 52, 3034 (2011).

3. U. Rashid, F. Anwar and G. Knothe, Biomass Bioenerg., 35, 4034 (2011).

4. L. Wang, Forest Resour. Manag., 5, 65 (2011) (in Chinese).

5. J. Zhang, Chinese Fruit Species, Apricot Volume. China Forestry Publishing House, Beijing (2003). (in Chinese).

6. Y. Luo and M. Liu, China Biotechnol., 27, 68 (2007) (in Chinese)

7. L. Wang, Forest Res., 23, 435 (2010) (in Chinese).

8. J. Zhang, D. Fu, Z. Wei, H. Zhao and T. Zhang, Acta Ecol. Sin., 26, 467 (2006).

9. E.P. Kris, P.S. Yu, J. Sabateé, H. Ratcliffe, G. Zhao and T. Etherton, Nut. Rev., 4, 103 (2001).

10. H.K. Chang, M.S. Shin, H.Y. Yang, J.W. Lee, Y.S. Kim, M.H. Lee, J. Kim, K.H. Kim and C.J. Kim, Biol. Pharm. Bull., 29, 1597 (2006).

11. L. Wang, J. Zhejiang Forestry Sci. Technol., 28, 76 (2008) (in Chinese).

12. H.V. Lee, R. Yunus, J.C. Juan and Y.H. Taufiq-Yap, Fuel Proc. Technol., 92, 2420 (2011).

13. U. Rashid, H.A. Rehman, I. Hussain, M. Ibrahim and M.S. Haider, Energy, 36, 5632 (2011).

14. S.G. Bojan, S. Chelladurai and S.K. Durairaj, Int. J. Green Energy, 8, 607 (2011). 